\title{
Sciendo
}

RESEARCH PAPERS FACULTY OF MATERIALS

SCIENCE AND TECHNOLOGY IN TRNAVA

SLOVAK UNIVERSITY OF TECHNOLOGY

IN BRATISLAVA

2018, Volume 26, Number 42

DOI 10.2478/rput-2018-0009

\section{COMPARATIVE ANALYSIS OF THE RESULTS OF MEASURING ROUNDNESS}

\author{
Imre NÉMEDI ${ }^{1}$, Róbert SÁNTA ${ }^{1}$, Igor FÜRSTNER ${ }^{1}$, Peter KOŠT'ÁL ${ }^{2}$ \\ ${ }^{1}$ Subotica TeCh - College of ApPliEd SCIENCES, \\ 24000 SubOticA, SERBIA \\ e-mail: nimre@vts.su.ac.rs, santa@vts.su.ac.rs \\ ${ }^{2}$ SLOVAK University OF TeCHNOLOGY IN BRATISLAVA, \\ FACULTY OF MATERIALS SCIENCE AND TECHNOLOGY IN TRNAVA, \\ INSTITUTE OF PRODUCTION TECHNOLOGIES, \\ Ulica JÁna Bottu 2781/25, 91724 TRnAVA, SLOVAK REPUbliC \\ e-mail: peter.kostal@stuba.sk \\ Received: 29.05.2018, Accepted: 19.06.2018, Published: 19.09.2018
}

\begin{abstract}
Coordinate measuring machines are devised for most complex measurements. Besides their dimension measuring abilities, the CNC operated machines can measure geometrical characteristics of form, such as straightness, roundness, cylindricity, etc. These are vital features currently, when inspection needs to submit very thorough reports not only on the form, but also on the geometrical features of the given workpiece. Yet the question arises: are these measuring data regarding roundness received from the CMM accurate and reliable enough to be exploited? In order to confirm this statement, the geometrical roundness characteristics were measured on three types of coordinate measuring machines, the results of which were analyzed from several aspects. The results showed a special importance of specific measuring parameters and proved to be independent of the type of measuring machines.
\end{abstract}

\section{Key words}

Coordinate measuring machines, measuring roundness, circularity

\section{INTRODUCTION}

All workpieces have certain micro and macro geometrical surface characteristics as for deviation from dimension and macro geometrical characteristics regarding form, location, and direction $(1,2,3,4)$ that pose functional limitations which, if overstepped, this may endanger the functionality of the workpiece. The tolerances on the drawings (PLANS, DESIGNS) have to completely ensure the dimensions and geometrical form, so that nothing is left to subjective evaluation of the factory staff or the inspection service (3). 
The forms of the real surfaces regularly have a certain degree of deviation in comparison to the geometrically ideal surfaces. The causes of deviation basically match with the causes of inaccuracy of measuring workpieces. Functional dimensions are always done with a certain degree of tolerance that simultaneously limits the form deviation of that workpiece.

If one needs a greater degree of precision than the one provided by the tolerance level formed by the tolerance of longitudinal dimensions, then the form must be separately tolerated. All this is true for location between two or more surfaces. The exceptions for this are: symmetry, coaxiality and precision of rotation, as they are independent of real dimensions, and they are determined in relation to the central plain and the axis $(2,5,6$ and 7).

Geometrical tolerances are determined only when necessary from the aspect of functional requirements, exchangeability or production. However, this does not mean automatically that a special way of manufacture, measuring or inspection has to be used. One specific version of form tolerance, namely roundness, is analysed in this paper (2, 5 and 8).

For the purposes of this analysis, the following measuring machines were used:

PRISMO MPS - CARL ZEISS Industrial Metrology, (9)

$>$ DEA - Hexagon Metrology and

$>$ Crysta - Apex C776 - Mitutoyo.

\section{DEFINITION OF TOLERANCE OF ROUNDNESS}

The field of roundness tolerance in the regarded plain is restricted by two concentric circles at the distance $t$. (Fig. 1)

If the section lines are tolerated, then all section points must lie between two concentric circles on the section plain, at a radial distance of $t$. This parameter $t$ is the value of tolerance of roundness $(2,4)$.

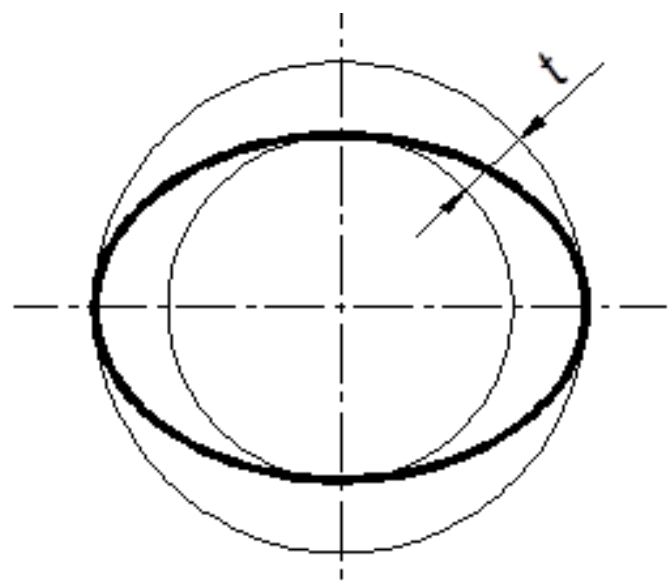

Fig. 1 Definition of tolerance of roundness $(2,4)$

\section{METHODS OF ROUNDNESS MEASUREMENT}

The above listed deviations from the ideal round forms are only of an orientational character. In reality, naturally, we will not receive finely defined forms, but the forms, where an entire procedure must be carried out in order to define which case this is. This is achieved by introducing various methods of filtration of the gained results. Based on the applied measuring instruments, the measurements and inspection can be grouped as follows: 
$>$ Inspection using single measuring instruments,

$>$ Inspection using multiple measuring instruments (micrometers for external and internal measurements with measurements in two or three points),

$>$ Inspection using special measuring instruments and fixtures, such as prisms for measurement and comparators; and

$>$ Inspection using diagrams which were gained by measurement on measuring machines (2).

The last group includes the measurement using CMM and special measuring machines. CMM, such as flexible metrological systems have the ability to record all necessary information about the workpiece for further analysis, as well as to measure various sizes of the piece. Current measuring machines have the capabilities to process all recorded data owing to the sophisticated software solutions, and so they can provide the final image of the analysed section in the form of a measurement report, in which all relevant measurement data are portrayed, as well as a graphical display of the received form of the workpiece (2).

\section{MEASUREMENTS}

Measurements were carried out in five different locations on the table, with the aim to exclude eventual errors which may have occurred due to an inaccurate motion mechanism of the carrier construction of the measuring machine. The locations are presented in Fig. 2.

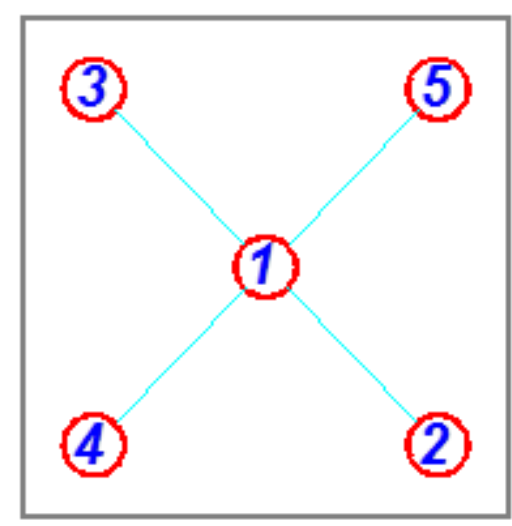

Fig. 2 Setup of the measurement locations on the machine table (2)

\section{Measurement workpieces}

Measurement workpieces used for the implementation of the experimental measurements are versatile from the aspect of dimensions and locations of measurement plains. We chose master rings (measurement of interior surfaces), a tolerance measurement for the master plug, and a pivot, produced by the ATB SEVER Company as part of the centrifugal pump construction - high quality accuracy considering dimensions, roundness, and cylindricity.

The tolerance master plug and pivot are representations for measurements of exterior surfaces. The dimensions chosen for measurement workpieces were as follows:

Master rings of the diameter $\mathrm{D}=\varnothing 49.991 \mathrm{~mm}$ and $\mathrm{D}=\varnothing 30 \mathrm{~mm}$,

$>$ Master plug of the diameter of $\mathrm{d}=\varnothing 80$,

Finally, the pivot of the diameter $Ø 12 \mathrm{~mm}$.

All measurement workpieces are made of high quality steel, thermally processed and ground. 


\section{Presentation of the used measurement machines}

This section presents the used coordinate measuring machines and special measuring machines for measuring roundness.

a) Coordinate measuring machine PRISMO MPS - CARL ZEISS Industrial Metrology

Measuring uncertainty $\left(\mathrm{MPE}_{\mathrm{E}}\right):(2.7+\mathrm{L} / 300) \mu \mathrm{m}$, where $\mathrm{L}$ is the length in $\mathrm{mm}$.

b) Coordinate measuring machine DEA - Hexagon Metrology

Measuring uncertainty $\left(\mathrm{MPE}_{\mathrm{E}}\right):(0.9+\mathrm{L} / 350) \mu \mathrm{m}$, where $\mathrm{L}$ is the length in $\mathrm{mm}$.

c) Coordinate measuring machine Crysta - Apex C776 - Mitutoyo

Measuring uncertainty $\left(\mathrm{MPE}_{\mathrm{E}}\right):(1.7+0.4 \mathrm{x} \mathrm{L/350}) \mu \mathrm{m}$, where $\mathrm{L}$ is the length in $\mathrm{mm}$.

d) Measuring roundness on the special machine for determining roundness Roundtest RA2100 - Mitutoyo

The aim of this measurement was to gain accurate data regarding roundness, which will be used as reference in comparative analysis of measuring capabilities of the coordinate measuring machine.

The most important technical parameters of this measuring machine are:

$>$ rotational accuracy on radial direction: $(0.02+3.8 \mathrm{H} / 10000) \mu \mathrm{m}(\mathrm{H}-$ the height of the workpiece given in $\mathrm{mm}$ ),

measuring force: $7-40 \mathrm{mN}$,

stylus tip form: $\phi 1.6 \mathrm{~mm}$.

\section{GAINED RESULTS}

Measurement of roundness was carried out on the three described types of CMM. When distributing the measurement workpieces to the various machines, it was vital that, on all machines, the interior and exterior surfaces were measured by the same measuring probes. The distribution of measurement workpieces on the measuring machines was as follows:

1) On the DEA - Hexagon Metrology type machine we measured: pivot $\phi 12 \mathrm{~mm}$ and master ring $\phi 30 \mathrm{~mm}$.

2) On the PRISMO MPS - CARL ZEISS Industrial Metrology type machine we measured: master plug $\phi 80 \mathrm{~mm}$ and master ring $\phi 49.991 \mathrm{~mm}$.

3) Finally, for comparative results to the coordinate measuring machines, all pieces were also pre-measured on the Crysta Apex C776 - Mitutoyo type machine.

On the first two machines, the measurements were carried out in five measuring positions. The results will be displayed indexed by the numbers $1-5$, depending on the measuring locations. Simultaneously, a comparison of those results was carried out depending on the measuring location. Finally, the comparison of the results from the first two machines and the third one - Mitutoyo, was carried out, comparing the results with the diagram from the Roundtest RA-2100 - Mitutoyo measuring machine. In all cases, a type B filter was used, according to the British standard BS 3730-1964. 


\section{Measuring the $\phi \mathbf{3 0} \mathrm{mm}$ master ring}

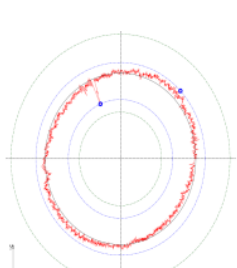

1.

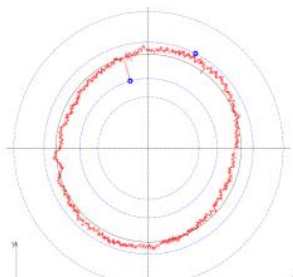

2.

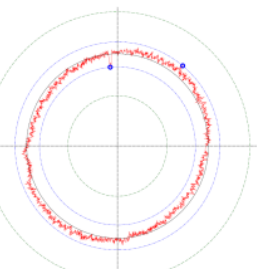

3.

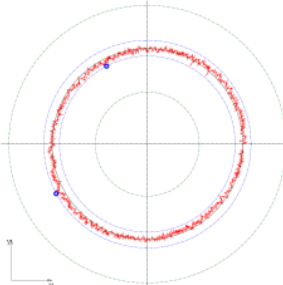

4.

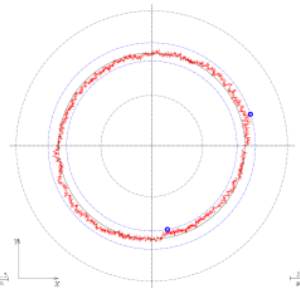

5.

Fig. 3 Results of measuring the $\phi 30 \mathrm{~mm}$ master ring

\section{Measuring the $\phi 80 \mathrm{~mm}$ master plug}

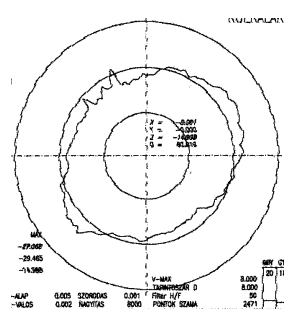

1.

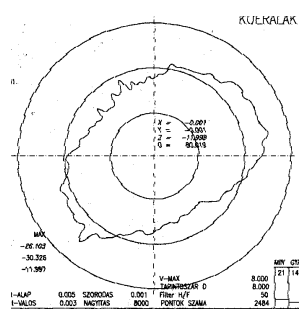

2.

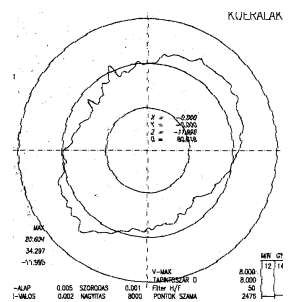

3.

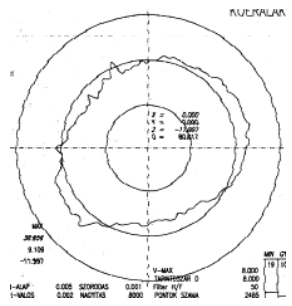

4.

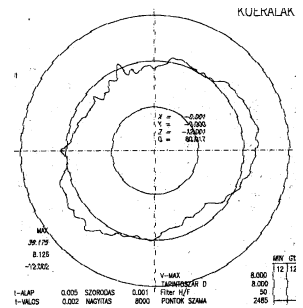

5.

Fig. 4 Results of measuring the $\phi 80 \mathrm{~mm}$ master plug

\section{Measuring the $\phi 12 \mathrm{~mm}$ pivot}

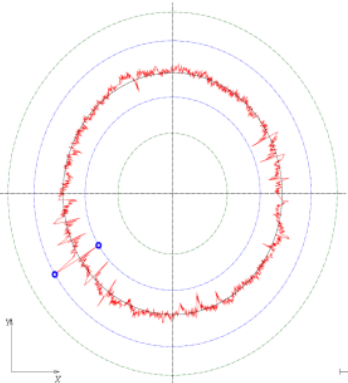

DEA

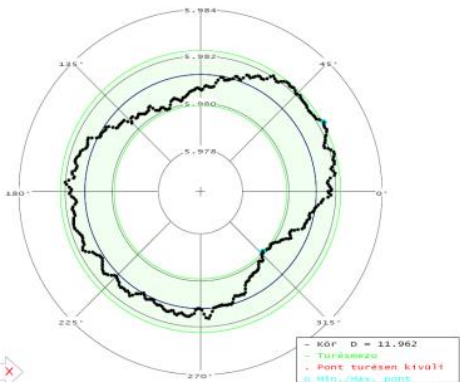

Crysta - Apex

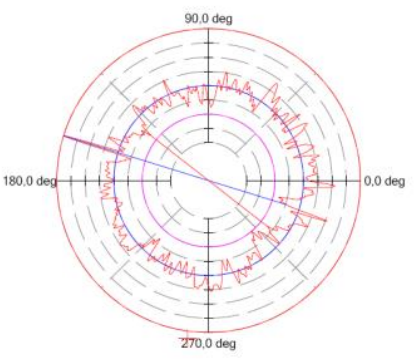

Roundtest

Fig. 5 Comparison of results of measuring the $\phi 12 \mathrm{~mm}$ pivot 


\section{Measuring the $\phi 30 \mathrm{~mm}$ master ring}

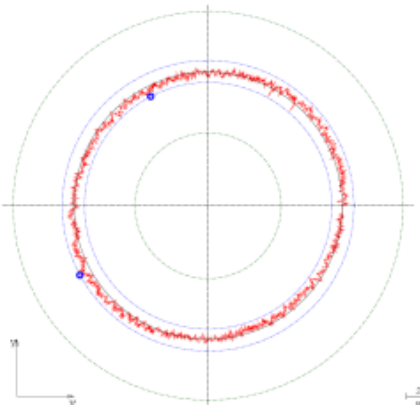

DEA

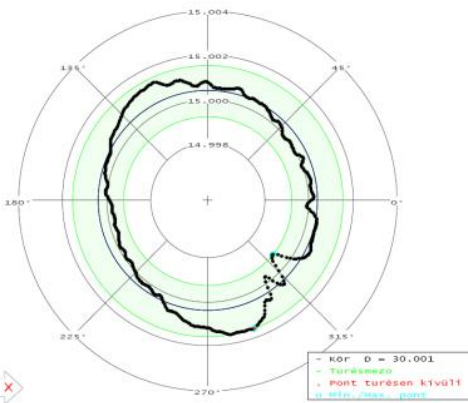

Crysta - Apex

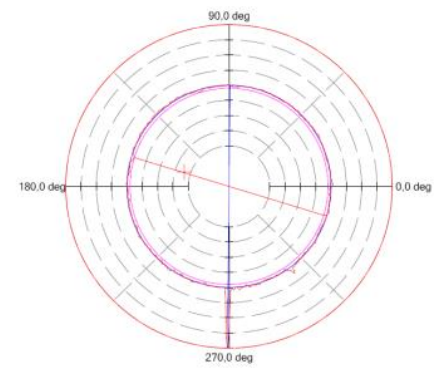

Roundtest

Fig. 6 Comparison of results of measuring the $\phi 30 \mathrm{~mm}$ master ring

\section{Measuring the $\phi 80 \mathrm{~mm}$ master plug}

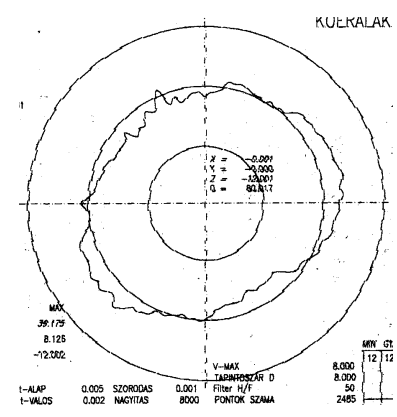

PRISMO MPS

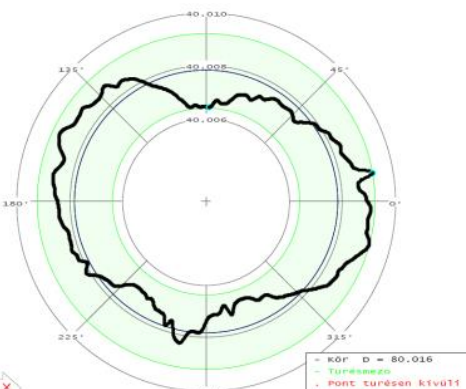

Crysta - Apex
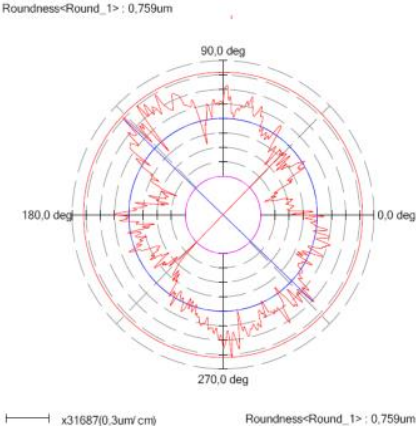

Roundtest

Fig. 7 Comparison of results of measuring the $\phi 80 \mathrm{~mm}$ master plug

\section{Measuring the $\phi 49.991 \mathrm{~mm}$ master ring}

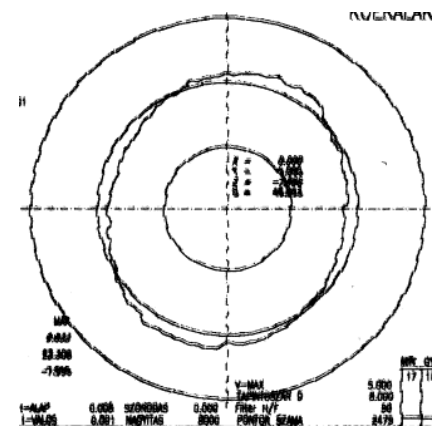

PRISMO MPS

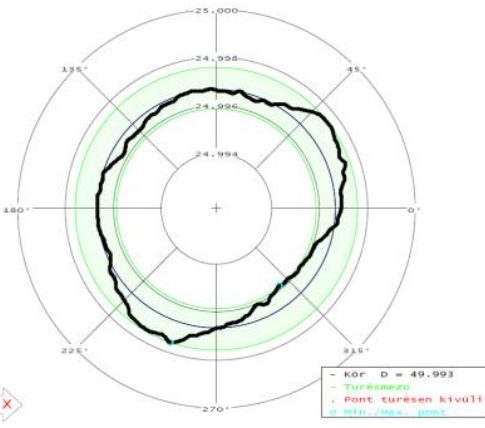

Crysta - Apex

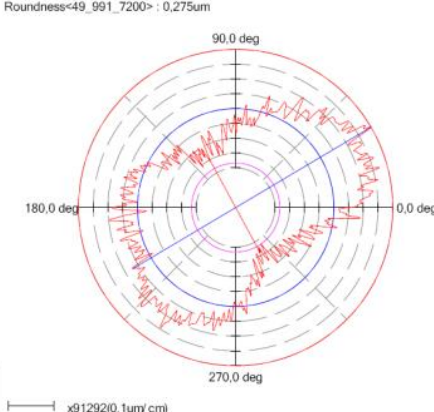

Roundtest

Fig. 8 Comparison of results of measuring the $\phi 49.991 \mathrm{~mm}$ master ring 


\section{Tabular presentation of results of the roundness measurements}

The next table gives the results of the roundness measurements for each methods.

\begin{tabular}{|l|c|c|c|c|}
\hline \multicolumn{6}{|c|}{ Table 1: Results of the roundness measurements in $\mu \mathrm{m}$} \\
$\begin{array}{c}\text { Measurement of } \\
\text { workpieces }\end{array}$ & $\begin{array}{c}\text { DEA - } \\
\text { Hexagon } \\
\text { Metrology }\end{array}$ & $\begin{array}{c}\text { PRISMO } \\
\text { MPS - } \\
\text { CARL ZEISS }\end{array}$ & $\begin{array}{c}\text { Crysta Apex } \\
\text { C776 - } \\
\text { Mitutoyo }\end{array}$ & $\begin{array}{c}\text { Roundtest } \\
\text { RA-2100 - } \\
\text { Mitutoyo }\end{array}$ \\
\hline pivot $\phi 12 \mathrm{~mm}$ & $3 ., 15$ & 3.79 & 2.68 & 0.893 \\
\hline master ring $\phi 30 \mathrm{~mm}$ & 1.17 & 2.21 & 1.45 & 0.452 \\
\hline master plug $\phi 80 \mathrm{~mm}$ & 2.82 & 3.26 & 2.25 & 0.759 \\
\hline master ring $\phi 49.991 \mathrm{~mm}$ & 2.43 & 3.04 & 2.17 & 0.654 \\
\hline
\end{tabular}

\section{CONCLUSIONS}

Based on the described facts and comparisons of the measurement results, the following can be stated:

The used machines for determining roundness globally give reliable results concerning the form of deviation of roundness.

Recognizing the form of deviation depends to a great degree on the optimal magnification. This can be seen in the case of the CMM DEA - Hexagon Metrology, where the magnification was about 4000 times, thus reading the deviation from the form of the diagram was more difficult. Magnification with the other two measuring machines was about 8000 times, thus the form was easily recognizable.

$>$ In the cases where the extreme points are recognizable, all measuring machines ensure their location and calculate their location except with special machines for roundness, which is not meant for such tasks,

It is important to note that all measured bandwidths of roundness with coordinate measuring machines for the same measurement workpieces were identical or extremely close. This means that the results of the measurement of roundness in these cases did not significantly depend on the size of the measuring uncertainty. Hence, this parameter moved in a rather wide range in the three coordinate measuring machines used. This aspect will need further research.

As far as accuracy of determining bandwidth of roundness is concerned, the coordinate measuring machine which was not specifically aimed at this type of Inspection and measurement, providing about 3-5 time higher values than the results on the roundness machine. Taking into consideration that the sizes in question are only several micrometers, it can be stated that, in production where the tolerance level is usually about one hundredth of a millimeter, the coordinate measuring machines perfectly satisfy the present needs in determining the roundness of the workpieces. 


\section{References:}

1. STEVIĆ, M. 2006. Povećanje točnosti merenja numerički upravljanih mernih mašina (Increasing the measuring accuracy of numerically controlled measuring machines). (Monograph). Novi Sad, Fakultet tehničkih nauka, FTN Izdavaštvo,

2. NEMEDI, I. 2009. Vrednovanje sistema za merenje kružnosti, magistarski rad (Evaluation of the circular measuring system). (Master thesis). Novi Sad, Fakultet tehničkih nauka.

3. MAJSTOROVIĆ, V., HODOLIČ, J. 1998. Numerički upravljane merne mašine (Numerically controlled measuring machines). Novi Sad, Fakultet tehničkih nauka, Institut za proizvodno mašinstvo,

4. SZILÁGYI, L. 1982. Gépipari hosszmérések, Ipari szakkönyvtár (Industrial library of length measurements in machine industry). Budapest, Müszaki Könyvkiadó,

5. GRAHAM, B. 2002. Scanning and digitising solutions, Metrology Division. Renishaw, USA.

6. MÁTÉ, M., HOLLANDA, D. 2017. About the Profile Accuracy of the Involute Gear Hob. Acta Universitatis Sapientiae Electrical and Mechanical Engineering, 9(1) pp. 5-19.

7. PÁSZTOR, J., FORGÓ, Z., VLAD, C. 2013. The Dynamic Modeling of the Oscillating Harrow`s Fangs. In: OGÉT 2013 XXI Nemzetközi Gépészeti Találkozó, EMT, pp.310-314. Arad, Romania.

8. GARBAI, L., JASPER, A. 2017. Operation of looped district heating networks. Periodica Polytechnica-Mechanical Engineering, 61(2) pp. 79-86.

9. Table-Rotating Type Roundness Measuring / Cylindrical Profile Measuring Instruments, Rondcom_Accsy.pdf, Tokio Seimitsu, Japan, 2003. (www.zeiss.de)

\section{ORCID:}

Peter Košt’ál 0000-0001-6622-6174 